\title{
Highly Specific Detection of Five Exotic Quarantine Plant Viruses using RT-PCR
}

\author{
Hoseong Choi, Won Kyong Cho, Jisuk Yu, Jong-Seung Lee and Kook-Hyung Kim* \\ Department of Agricultural Biotechnology, Plant Genomics and Breeding Institute, Institute for Agriculture and Life Sciences, \\ College of Agriculture and Life Sciences, Seoul National University, Seoul 151-921, Korea \\ (Received on September 12, 2012; Revised on October 3, 2012; Accepted on October 3, 2012)
}

To detect five plant viruses (Beet black scorch virus, Beet necrotic yellow vein virus, Eggplant mottled dwarf virus, Pelargonium zonate spot virus, and Rice yellow mottle virus) for quarantine purposes, we designed 15 RT-PCR primer sets. Primer design was based on the nucleotide sequence of the coat protein gene, which is highly conserved within species. All but one primer set successfully amplified the targets, and gradient PCRs indicated that the optimal temperature for the 14 useful primer sets was $51.9^{\circ} \mathrm{C}$. Some primer sets worked well regardless of annealing temperature while others required a very specific annealing temperature. A primer specificity test using plant total RNAs and cDNAs of other plant virusinfected samples demonstrated that the designed primer sets were highly specific and generated reproducible results. The newly developed RT-PCR primer sets would be useful for quarantine inspections aimed at preventing the entry of exotic plant viruses into Korea.

Keywords : Beet black scorch virus, Beet necrotic yellow vein virus, Eggplant mottled dwarf virus, Pelargonium zonate spot virus, Rice yellow mottle virus

With the worldwide increase in trade among nations during last two decades, the number of exotic plants, including crops, fruits, and vegetables, that have been imported into Korea, has dramatically increased. Preventing the entry or spread of exotic pathogens that frequently accompany this plant material into Korea and into other countries relies in part on quarantine inspections. Although the Animal, Plant and Fisheries Quarantine and Inspection Agency (QIA) in Korea attempts to prevent the entry of all quarantined pathogens in imported plants, the identification of exotic plant pathogens and especially of viruses can be difficult because the host range of many plant viruses includes both known and unknown plant species. In addition, plant viruses may be present but may cause disease symptoms only under specific conditions. It is, therefore, important that

\footnotetext{
*Corresponding author.

Phone) +82-2-880-4677, FAX) +82-2-873-2317

E-mail)kookkim@snu.ac.kr
}

quarantine agencies must have the ability to detect and identify plant viruses in both symptomatic and symptomless plants of all plant species.

In this study, we developed an improved method for the detection of five quarantine viruses in Korea: Beet black scorch virus (BBSV), Beet necrotic yellow vein virus (BNYVV), Eggplant mottled dwarf virus (EMDV), Pelargonium zonate spot virus (PZSV), and Rice yellow mottle virus (RYMV). Although these viruses have not been reported in Korea, they could infect economically important plants in this country if introduced. BBSV and BNYVV cause rhizomania disease of sugar beet (Jiang et al., 1999; Tamada and Kusume, 1991). Interestingly, both viruses are transmitted by fungal vectors; BBSV is transmitted in a non-persistent manner by zoospores of Olpidium brassicae (Jiang et al., 1999) while BNYVV is transmitted by the soil-borne fungus Polymyxa betae (Tamada and Kusume, 1991). BBSV is a member of the genus Necrovirus, and its genome consists of 3,641 bp that encode six proteins (Cao et al., 2002). BNYVV is a member of the genus Benyvirus and is composed of four or five RNA segments (Kiguchi et al., 1996; Saito et al., 1996). Although BBSV and BNYVV have not yet been reported in Korea, they have been reported in most other parts of the world (Cai et al., 1993; Chiba et al., 2011; González-Vázquez et al., 2009; Koenig and Valizadeh, 2008; Weiland et al., 2006). Mechanical inoculation demonstrated that BBSV has a wide host range and produces local lesions on Chenopodium amaranticolor, C. quinoa, C. murale, Spinacia oleracea, and Tetragonia expansa (Cai et al., 1993). BBSV also latently infects Lactuca sativa, Physalis florisana, and Nicotiana species (Cai et al., 1993). Aside from sugar beet, BNYVV also infects various spinach cultivars (Mou et al., 2012).

EMDV is a rhabdovirus, transmitted by a leafhopper (Babaie and Izadpanah, 2003) and infects many plants such as Capparis spinosa, cucumber, eggplant, tomato, Pittosprum tobira, potato, and tobacco (Katis et al., 2011; Mavriè et al., 2006). PZSV, belongs to the family Bromoviridae, was originally isolated from Pelargonium zonale and has a wide host range that includes tomato, globe artichoke, Capsella bursa-pastoris, Chrysanthemum segetum, 
Diplotaxis erucoides, Picris echioides, and Sonchus oleraceus (Finetti-Sialer and Gallitelli, 2003; Quacquarelli and Gallitelli, 1979). The genome of PZSV consists of three RNA segments, one of which encodes a polypeptide with a molecular mass of $108 \mathrm{kDa}$ (Finetti-Sialer and Gallitelli, 2003). RYMV was first reported in Kenya in 1966 (Hebrard et al., 2009) and so far has been detected only in Africa. The host range of RYMV includes two cultivated rice species, Oryza sativa and $O$. glaberrima, as well as some wild grasses (Allarangaye et al., 2007). RYMV is a member of the genus Sobemovirus, encodes four proteins, and is transmitted by various beetles belonging to the Chrysomelidae family (Bakker, 1974; Fargette et al., 2002; Yassi et al., 1994).

Since these five viruses have relatively wide host ranges, it is likely that their introduction would result in their establishment and spread among vegetables and weeds in Korea. To accurately and rapidly detect RNA viruses, researchers have developed methods based on reverse transcription-polymerase chain reaction (RT-PCR) (Lee et al., 2004; Lee et al., 2011a, 2011b). In the current study, we designed RT-PCR primer sets for the detection of the five quarantine viruses described in the previous paragraphs. We also demonstrate the utility and specificity of these primer sets.

Background information for the five viruses is provided in Table 1. Virus-infected plant tissues were obtained from DSMZ GmbH in Germany (http://www.dsmz.de/) with strict control by the QIA. To design RT-PCR primer sets specific for each virus, we used the genes encoding the capsid protein (CP) because these nucleotide sequences are conserved within viruses. Nucleotide sequences for each virus were down-loaded from the National Center for Biotechnology Information (NCBI). Three primer sets (designated \#1, \#2, and \#3) were designed for each of the five viruses (Table 2).

Total RNA was extracted using Isol-RNA lysis reagent (5 Prime, Gaithersburg, USA) following the manufacturer's instruction. To determine the quality and quantity of the isolated total RNAs, we loaded the extracted RNA samples on $1 \%$ TAE agarose gel; after electrophoresis, the RNA was visualized by ethidium bromide (EtBr) staining, and the RNA concentration in each sample was measured with the Nanophotomer ${ }^{\mathrm{TM}}$ (Implen GmbH, Munich, Germany). The extracted total RNAs were of high quality and of sufficient quantity to synthesize cDNAs (Fig. 1). The first strand cDNA was synthesized as described previously (Lee et al., 2011a, 2011b). Briefly, $1 \mu \mathrm{g}$ of each total RNA, 10 pmoles of each reverse primer, and sufficient DEPC-treated water were combined to a total volume of $5 \mu \mathrm{l}$. The samples were kept at $70.0^{\circ} \mathrm{C}$ for $5 \mathrm{~min}$ and then in ice for $5 \mathrm{~min}$. After 5 $\mu \mathrm{l}$ of $2.5 \mathrm{mM}$ dNTP, $5 \mu \mathrm{l}$ of $5 \times$ GoScript $^{\mathrm{TM}}$ reaction buffer, $1.5 \mu \mathrm{l}$ of $25 \mathrm{mM} \mathrm{MgCl}_{2}, 1 \mu \mathrm{l}$ of GoScript ${ }^{\mathrm{TM}}$ reverse transcriptase (Promega, Madison, USA), and $3.5 \mu$ l of DEPCtreated water were added, the samples were incubated at $42^{\circ} \mathrm{C}$ for $1 \mathrm{~h}$. The reverse transcription reaction was stopped by incubating samples at $70^{\circ} \mathrm{C}$ for $15 \mathrm{~min}$.

PCR was conducted in $50 \mu \mathrm{l}$ of PCR mixture containing $1 \mu \mathrm{l}$ of five-fold diluted cDNA, $2 \mu \mathrm{l}$ of each primer set at 10 pmole $5 \mu \mathrm{l}$ of $10 \times$ PCR buffer, $1 \mu \mathrm{l}$ of $2.5 \mathrm{mM}$ dNTP, 0.25 $\mu \mathrm{l}$ of Ex-Taq polymerase (Takara, Otsu, Japan), and 40.75 $\mu \mathrm{l}$ of $\mathrm{dH}_{2} \mathrm{O}$; in the first PCRs, only primer set \#1 for each virus (see Table 2) was used. The PCR reactions were carried out with a $\mathrm{C} 1000^{\mathrm{TM}}$ thermal cycler (BIO-RAD, Hercules, USA) as follows: an initial denaturation at $94^{\circ} \mathrm{C}$ for $5 \mathrm{~min}$; followed by 30 cycles of denaturation at $94^{\circ} \mathrm{C}$ for $30 \mathrm{sec}$, annealing at $50^{\circ} \mathrm{C}$ for $30 \mathrm{sec}$, and extension at $72^{\circ} \mathrm{C}$ for 30 sec; and a final extension at $72^{\circ} \mathrm{C}$ for $5 \mathrm{~min}$. A $5-\mu 1$ quantity of amplified PCR product was examined in a $1 \%$ TAE agarose gel, which was stained with $\mathrm{EtBr}$ for UV visualization. PCR products of the expected sizes were obtained for the five primer sets (Fig. 2; lanes 1, 4, 7, 10, and 13), and the nucleotide sequences of each amplified PCR fragment were confirmed by DNA sequencing.

When we conducted RT-PCR reactions with all 15 primer

Table 1. The five quarantine plant viruses for which RT-PCR primers were designed in the current study

\begin{tabular}{|c|c|c|c|c|c|}
\hline Virus name & Family & Genus & Type & $\begin{array}{l}\text { No. of RNA } \\
\text { fragments }\end{array}$ & Host plants \\
\hline $\begin{array}{l}\text { Beet black scorch virus } \\
\text { (BBSV) }\end{array}$ & Tombusviridae & Necrovirus & $\begin{array}{l}\text { ssRNA positive- } \\
\text { strand viruses }\end{array}$ & 1 & $\begin{array}{l}\text { Sugar beet, spinach, } \\
\text { lettuce }\end{array}$ \\
\hline $\begin{array}{c}\text { Beet necrotic yellow vein virus } \\
\text { (BNYVV) }\end{array}$ & Unclassified & Benyvirus & $\begin{array}{l}\text { ssRNA positive- } \\
\text { strand viruses }\end{array}$ & 5 & Sugar beet, spinach \\
\hline $\begin{array}{c}\text { Eggplant mottled dwarf virus } \\
\text { (EMDV) }\end{array}$ & Rhabdoviridae & Nucleorhabdovirus & $\begin{array}{l}\text { ssRNA negative- } \\
\text { strand viruses }\end{array}$ & 1 & $\begin{array}{l}\text { Eggplant, Hibiscus } \\
\text { rosasinensis, tomato }\end{array}$ \\
\hline $\begin{array}{c}\text { Pelargonium zonate spot virus } \\
\text { (PZSV) }\end{array}$ & Bromoviridae & Anulavirus & $\begin{array}{l}\text { ssRNA positive- } \\
\text { strand viruses }\end{array}$ & 4 & $\begin{array}{l}\text { Tomato, globe artichoke, } \\
\text { Capsella bursa-pastoris }\end{array}$ \\
\hline $\begin{array}{c}\text { Rice yellow mottle virus } \\
\text { (RYMV) }\end{array}$ & Unclassified & Sobemovirus & $\begin{array}{l}\text { ssRNA positive- } \\
\text { strand viruses }\end{array}$ & 1 & $\begin{array}{l}\text { Rice (Oryza sativa and } \\
\text { O. glaberrima) }\end{array}$ \\
\hline
\end{tabular}


Table 2. The RT-PCR primers designed for detection of five quarantine plant viruses (BBSV, BNYVV, EMDV, PZSV and RYMV)

\begin{tabular}{|c|c|c|c|c|}
\hline Index & $\mathrm{Name}^{\mathrm{a}}$ & Sequence ( $5^{\prime}$ to 3 ') & $\operatorname{Tm}\left({ }^{\circ} \mathrm{C}\right)$ & $\begin{array}{l}\text { Expected length } \\
\text { (bp) }\end{array}$ \\
\hline 1 & BBSV_F_\#1 & CCCTCCACGTATTAGGTCCA & 53.6 & 447 \\
\hline 2 & BBSV_R_\#1 & ATAGCGGCTAAGGTTGCGTA & 54.1 & \\
\hline 3 & BBSV_F_\#2 & TGGTACGCGAGTATCCAACA & 53.7 & 447 \\
\hline 4 & BBSV_R_\#2 & TTCCTGTCGTTTGCAGTGAG & 53.4 & \\
\hline 5 & BBSV_F_\#3 & TGCATTTTCTGTCGTTGGAG & 53.3 & 453 \\
\hline 6 & BBSV_R_\#3 & CCAACATTAGTCGCAGCAGA & 53.6 & \\
\hline 7 & BNYVV_F_\#1 & GATCGATGGGCCCGTGTTTC & 60.8 & 475 \\
\hline 8 & BNYVV_R_\#1 & CAGGTGTCCATGGTAACTTCAAC & 54.8 & \\
\hline 9 & BNYVV_F_\#2 & TTCGGACGTCGTGAGTGTTA & 53.7 & 391 \\
\hline 10 & BNYVV_R_\#2 & AAGAGCTTGAGCCAAACCAG & 53.4 & \\
\hline 11 & BNYVV_F_\#3 & TCCAAGGCTGCGAATCTATC & 54.1 & 373 \\
\hline 12 & BNYVV_R_\#3 & CCCGAGTCCACATTAATTCC & 53.1 & \\
\hline 13 & EMDV_F_\#1 & AACATGTTCATGATAAGGAATGTAGA & 52.8 & 233 \\
\hline 14 & EMDV_R_\#1 & CGAATGGAGTTGGGGTTG & 53.1 & \\
\hline 15 & EMDV_F_\#2 & TTCATGATAAGGAATGTAGATACAGGA & 54.3 & 222 \\
\hline 16 & EMDV_R_\#2 & GGAGTTGGGGTTGGCTCT & 53.4 & \\
\hline 17 & EMDV_F_\#3 & ACAGGAGACACTAATTGGTGGAA & 54.1 & 188 \\
\hline 18 & EMDV_R_\#3 & GCTCTGGGAGTCCATTGAAG & 53.3 & \\
\hline 19 & PZSV_F_\#1 & GACGCGCAAAGCTAGACAAAAC & 57.8 & 581 \\
\hline 20 & PZSV_R_\#1 & CTTGGCCAATCTTTTCGTGCTC & 59.6 & \\
\hline 21 & PZSV_F_\#2 & TGAATTTTCCGGGCTCTCTA & 53.7 & 402 \\
\hline 22 & PZSV_R_\#2 & TCAACTGTCTTCCCCGGATA & 54.1 & \\
\hline 23 & PZSV_F_\#3 & CAAGCTCATCCCTGGCTTTA & 54.2 & 400 \\
\hline 24 & PZSV_R_\#3 & GACAGTAGCGACCGGAGAGT & 53 & \\
\hline 25 & RYMV_F_\#1 & GAAGGGCAAGAAAACCAACTC & 54.2 & 597 \\
\hline 26 & RYMV_R_\#1 & GCTGGCAGTATGGTGTTTACG & 54.5 & \\
\hline 27 & RYMV_F_\#2 & GGATGGTTCCTGGTCCACTA & 53.3 & 481 \\
\hline 28 & RYMV_R_\#2 & GCTAGCCTTGCTGGCAGTAT & 53.6 & \\
\hline 29 & RYMV_F_\#3 & TTGAGTTCCTTGCGGACTTC & 54 & 400 \\
\hline 30 & RYMV_R_\#3 & TTGGGATCCACGCTACTAGG & 53.9 & \\
\hline
\end{tabular}

${ }^{a}$ Three primer sets (\#1, \#2, and \#3) were designed for each virus.

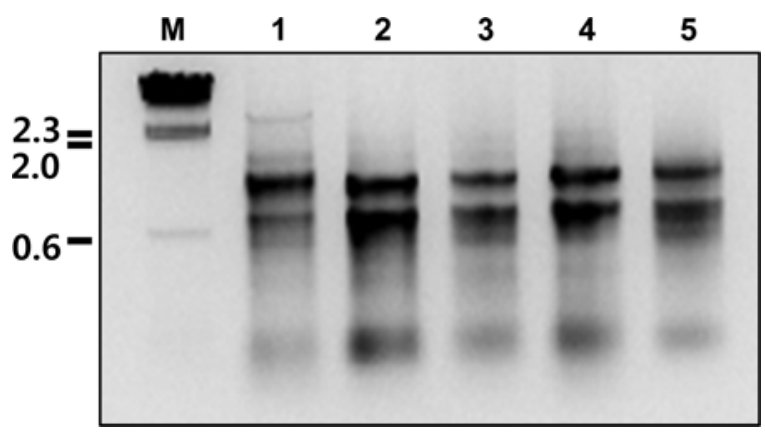

Fig. 1. Total RNAs extracted from plant tissues infected with five viruses. Lanes 1-5 contain total RNAs extracted from BBSV-, BNYVV-, EMDV-, PZSV-, and RYMV-infected plant tissues, respectively. Lane M indicates lambda DNA digested by HindIII as a molecular mass size marker. Numbers located to the left of the gel indicate sizes of digested lambda DNA in kilobase pairs. sets and the identical conditions described in the previous paragraph, all primer sets amplified PCR products of the expected sizes except for primer set RYMV_\#3 (Fig. 2; lane 15). However, the quantities of amplified PCR products were less with EMDV_\#2, EMDV_\#3, and PZSV_\#3 than with the other primer sets, indicating that annealing temperature or other conditions for RT-PCR amplification might not be optimal for these three primer sets.

To optimize annealing temperature for each primer set, we performed gradient PCRs with all 15 primer sets. The gradient PCRs were conducted with the following conditions: an initial denaturation at $94^{\circ} \mathrm{C}$ for $5 \mathrm{~min}$; followed by 25 cycles at $94^{\circ} \mathrm{C}$ for $30 \mathrm{sec}$, a gradient annealing temperature $\left(51.9,54\right.$, or $\left.55^{\circ} \mathrm{C}\right)$ for $30 \mathrm{sec}$, and $72^{\circ} \mathrm{C}$ for 30 sec; and a final extension at $72^{\circ} \mathrm{C}$ for $5 \mathrm{~min}$. The results are shown in Fig. 3. With primer sets BBSV_\#1 and BBSV_\#3, 


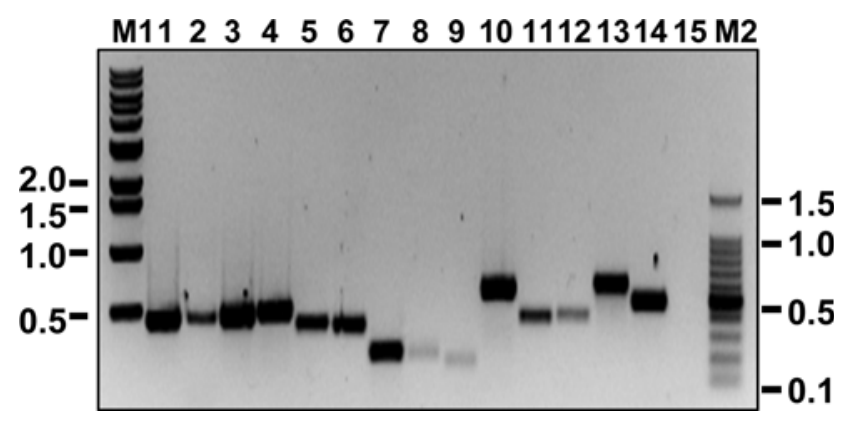

Fig. 2. RT-PCR amplification of virus-specific dsDNA fragments using virus-specific primer pairs corresponding to the $\mathrm{CP}$ regions. The number above each lane indicates the primer set (and corresponding virus fragment) used in the RT-PCR as follows: lane 1, BBSV \#1; lane 2, BBSV \#2; lane 3, BBSV \#3; lane 4, BNYVV \#1; lane 5, BNYVV \#2; lane 6, BNYVV \#3; lane 7, EMDV \#1; lane 8, EMDV \#2; lane 9, EMDV \#3; lane 10, PZSV \#1; lane 11, PZSV \#2; lane 12, PZSV \#3; lane 13, RYMV \#1; lane 14, RYMV \#2; lane 15, RYMV \#3. Lane M1 and M2 represent $1 \mathrm{~kb}$ molecular mass marker (Bioneer, Daejeon, Korea) and 100 bp DNA ladder (NEB, Herts, UK), respectively. Numbers on the sides of the gel indicate DNA sizes in kilobase pairs.

clear and substantial bands were obtained regardless of annealing temperature. With primer set BBSV_\#2, however, the quantity of PCR product gradually increased as the annealing temperature increased. For BBYVV, PCR products were obtained with all primers at each annealing temperature tested but PCR bands were thicker at $55^{\circ} \mathrm{C}$ than at other temperatures. Expected bands were obtained with EMDV primer sets at all three annealing temperatures but the band was faint with primer set EMDV_ $\# 3$ at $55^{\circ} \mathrm{C}$. Among the three primer sets for PZSV, only PZSV_\#1 amplified PCR products at all three temperatures. In contrast, primer sets PZSV_\#2 and PZSV_\#3 amplified PCR products only at $51.9^{\circ} \mathrm{C}$. For $\mathrm{RYMV}$, only primer set RYMV_\#1 could amplify PCR products at all three tested temperatures. With primer set RYMV_\#2, amplicons with faint bands were detected only at $54^{\circ} \mathrm{C}$ and $55^{\circ} \mathrm{C}$. The primer set RYMV_\#3 did not amplify any PCR product at the three temperatures, indicating that this primer set did not bind to the RYMV cDNA.

To be useful for quarantine purposes, the designed primer sets must not amplify sequences from other viruses or from the host genome. The specificity of 10 of the primer sets (BBSV_\#1, BBSV_\#3, BNYVV_\#1, BNYVV_\#3, EMDV_\#1, EMDV_\#2, PZSV_\#1, PZSV_\#2, RYMV_\#1, and RYMV_\#2) was tested using total RNA of tomato and tobacco and RNA obtained from Nicotiana benthamiana plants that had been inoculated with Potato virus $X(\mathrm{PVX})$ or Cucumber mosaic virus (CMV) 7 days earlier. Total RNAs were extracted from the uninfected tomato and tobacco plants as well as the infected $N$. benthamiana by the Trizol method, and cDNAs were synthesized as described earlier. PCRs were performed with cDNAs of the five quarantine viruses that were the focus of this study (as positive controls), with the genomic DNAs of $N$. benthamina and Solanum lycopersicum, and with the cDNAs derived from PVX- and CMV-infected $N$. benthamiana. PCRs with the 10 primer sets were performed as follows: an initial denaturation at $94.0^{\circ} \mathrm{C}$ for $5 \mathrm{~min}$; followed by 25 cycles at $94.0^{\circ} \mathrm{C}$ for $30 \mathrm{sec}, 50.0^{\circ} \mathrm{C}$ for $30 \mathrm{sec}$, and $72.0^{\circ} \mathrm{C}$ for $30 \mathrm{sec}$; and a final extension at $72.0^{\circ} \mathrm{C}$ for $5 \mathrm{~min}$. PCR products were obtained only with the positive controls (Fig. 4). No band was detected in samples containing genomic DNA of tobacco or tomato, and no band was detected with the cDNAs derived from PVX- or CMV-infected plants. These results indicate that the designed RT-PCR primer sets are specific for the target viruses.

In summary, we designed 15 primer pairs for PCR detection of five viruses (BBSV, BNYVV, EMDV, PZSV and RYMV). These five viruses, which have relatively wide host ranges, have not been detected in Korea but would cause substantial economic losses if they were able to establish in Korea. Fourteen of the 15 primer pairs (all except RYMV \#3) amplified the expected PCR products. Gradient PCRs indicated that $51.9^{\circ} \mathrm{C}$ was the optimal temperature for the

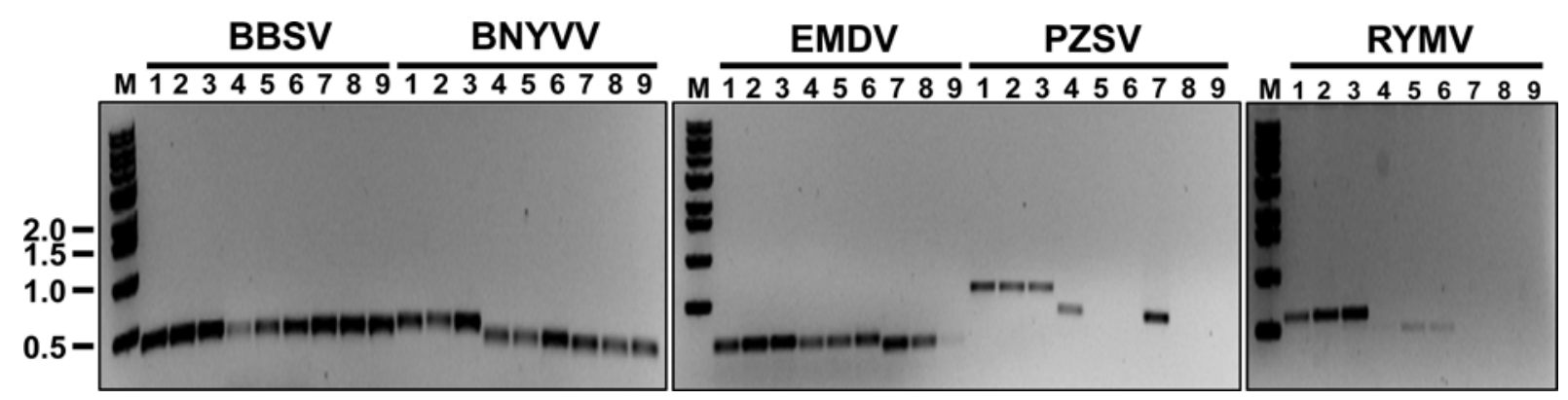

Fig. 3. Gradient RT-PCRs using three primer sets and three annealing temperatures for each virus. For each virus, lanes 1-3, 4-6, and 79 were obtained with primer sets $\# 1, \# 2$, and \#3, respectively. The annealing temperature used to obtain the products for each primer set was: $51.9^{\circ} \mathrm{C}$ for lanes 1,4 , and $7 ; 54.0^{\circ} \mathrm{C}$ for lanes 2,5 , and 8 ; and $55^{\circ} \mathrm{C}$ for lanes 3,6 , and 9 . Lane $\mathrm{M}$ indicates $1 \mathrm{~kb}$ molecular mass marker (Bioneer, Daejeon, Korea). Numbers located to the left of the gel indicate DNA sizes in kilobase pairs. 


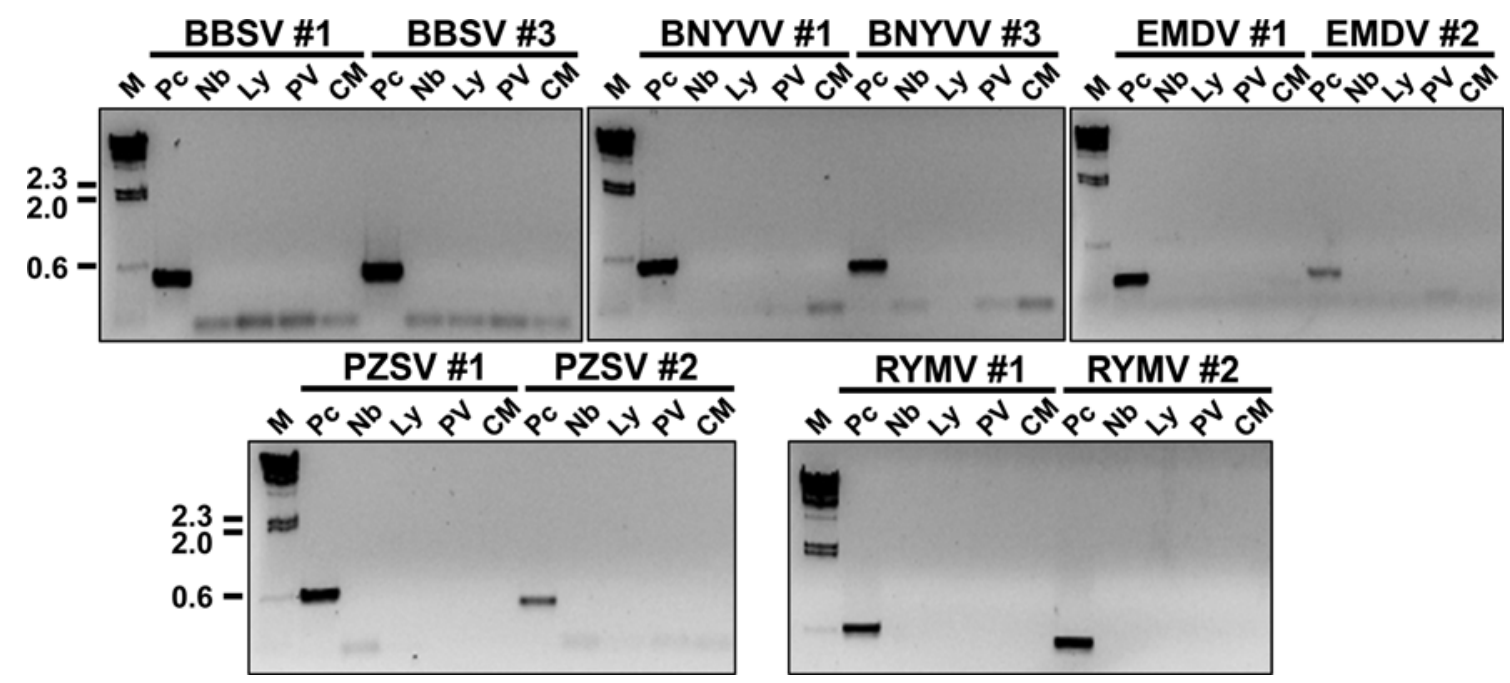

Fig. 4. Specificity of 10 of the newly designed primers for detection of BBSV, BNYVV, EMDV, PZSV, and RYMV by RT-PCR. Two primer pairs were tested for each quarantine virus. Amplified dsDNA fragments were separated in a $1 \%$ agarose gel and stained with EtBr. Pc represents the "positive control", the amplified dsDNA fragments for the target virus. Nb and Ly represent amplified dsDNA fragments corresponding to healthy Nicotiana benthamiana and healthy Lycopersicon esculentum, respectively. PV and CM represent amplified dsDNA fragments using total RNAs extracted from $N$. benthamiana infected with PVX and CMV, respectively. Lane M indicates lambda DNA digested by HindIII as a molecular mass size marker. Numbers located to the left indicate sizes of digested lambda DNA in kilobase pairs.

14 primer sets. Primer pairs BBSV_\#1 and BBSV_\#3 performed well regardless of annealing temperature while primer pairs PZSV \#2 and PZSV \#3 required a specific annealing temperature. A primer specificity test using plant genomic DNAs and cDNAs derived from the other plant viruses indicated that the primer sets were specific for the five target viruses. Taken together, the results indicate that the primer sets described here will be useful for detecting BBSV, BNYVV, EMDV, PZSV, and RYMV and preventing their entry into Korea.

\section{Acknowledgments}

This research was supported in part by grants from the Korea Institute of Planning and Evaluation for Technology of Food, Agriculture, Forestry and Fisheries (No. 30901504) and from the Rural Development Administration (Nos. PJ00819801 \& PJ007412). HC, WKC and JY were supported by the fellowships from the MEST through Brain Korea 21 Project.

\section{References}

Allarangaye, M., Traoré, O., Traoré, E., Millogo, R., Guinko, S. and Konate, G. 2007. Host range of Rice yellow mottle virus in Sudano-Sahelian Savannahs. Pakistan J. Biol. Sci. 10:1414.

Babaie, G. and Izadpanah, K. 2003. Vector transmission of Eggplant mottled dwarf virus in Iran. J. Phythopathol. 151:679682.
Bakker, W. 1974. Characterization and ecological aspects of Rice yellow mottle virus in Kenya. Agric. Res. Rep. 829.

Cai, Z., Chen, D., Wu, M., Cui, X., Yu, J. and Liu, Y. 1993. Identification of pathogenic virus of beet black scorch disease and detection by synthesized cDNA probes. J. Beijing Agric. Univ. 19:112.

Cao, Y., Cai, Z., Ding, Q., Li, D., Han, C., Yu, J. and Liu, Y. 2002. The complete nucleotide sequence of Beet black scorch virus (BBSV), a new member of the genus Necrovirus. Arch. Virol. 147:2431-2435.

Chiba, S., Kondo, H., Miyanishi, M., Andika, I. B., Han, C. and Tamada, T. 2011. The evolutionary history of Beet necrotic yellow vein virus deduced from genetic variation, geographical origin and spread, and the breaking of host resistance. Mol. Plant-Microbe Interact. 24:207-218.

Fargette, D., Pinel, A., Halimi, H., Brugidou, C., Fauquet, C. and Van Regenmortel, M. H. 2002. Comparison of molecular and immunological typing of isolates of Rice yellow mottle virus. Arch. Virol. 147:583-596.

Finetti-Sialer, M. and Gallitelli, D. 2003. Complete nucleotide sequence of Pelargonium zonate spot virus and its relationship with the family Bromoviridae. J. Gen. Virol. 84:3143-3151.

González-Vázquez, M., Ayala, J., García-Arenal, F. and Fraile, A. 2009. Occurrence of Beet black scorch virus infecting sugar beet in Europe. Plant Dis. 93:21-24.

Hebrard, E., Fargette, D., Konate, F. G., Inera, O. and Faso, B. 2009. Rice yellow mottle virus. Desk Encyclopedia Plant Fungal Virol. 88:302.

Jiang, J., Zhang, J., Che, S., Yang, D., Yu, J., Cai, Z. and Liu, Y. 1999. Transmission of Beet black scorch virus by Olpidium brassicae. J. Jiangxi Agric. Univ. 21:525-528. 
Katis, N. I., Chatzivassiliou, E. K., Clay, C. M., Maliogka, V. I., Pappi, P., Efthimiou, K., Dovas, C. I. and Avgelis, A. D. 2011. Development of an IC-RT-PCR assay for the detection of Eggplant mottled dwarf virus and partial characterization of isolates from various hosts in Greece. J. Plant Pathol. 93:353362.

Kiguchi, T., Saito, M. and Tamada, T. 1996. Nucleotide sequence analysis of RNA-5 of five isolates of Beet necrotic yellow vein virus and the identity of a deletion mutant. J. Gen. Virol. 77:575-580.

Koenig, R. and Valizadeh, J. 2008. Molecular and serological characterization of an Iranian isolate of Beet black scorch virus. Arch. Virol. 153:1397-1400.

Lee, B. Y., Lim, H. R., Choi, J. Y. and Ryu, K. H. 2004. Development of molecular detection of three species of seed-transmissible viruses useful for plant quarantine. Plant Pathol. J. 20:302-307.

Lee, J. S., Cho, W. K., Choi, H. S. and Kim, K. H. 2011a. RT-PCR detection of five quarantine plant RNA viruses belonging to poty- and tospoviruses. Plant Pathol. J. 27:291-296.

Lee, J. S., Cho, W. K., Lee, S. H., Choi, H. S. and Kim, K.-H. 2011b. Development of RT-PCR based method for detecting five non-reported quarantine plant viruses infecting the family Cucurbitaceae or Solanaceae. Plant Pathol. J. 27:93-97.
Mavriè, I., Tušek Žnidariè, M., Viršèek Marn, M., Dolnièar, P., Mehle, N., Lesemann, D. E. and Ravnikar, M. 2006. First report of Eggplant mottled dwarf virus in potato and tomato in Slovenia. Plant Pathol. 55:566-566.

Mou, B., Richardson, K., Benzen, S. and Liu, H. Y. 2012. Effects of Beet necrotic yellow vein virus in spinach cultivars. Plant Dis. 96:618-622.

Quacquarelli, A. and Gallitelli, D. 1979. Three viruses of Pelargonium zonale in Apulia. Phytopathol. Mediterr. 18:61-70.

Saito, M., Kiguchi, T., Kusume, T. and Tamada, T. 1996. Complete nucleotide sequence of the Japanese isolate $\mathrm{S}$ of Beet necrotic yellow vein virus RNA and comparison with European isolates. Arch. Virol. 141:2163-2175.

Tamada, T. and Kusume, T. 1991. Evidence that the $75 \mathrm{~K}$ readthrough protein of Beet necrotic yellow vein virus RNA-2 is essential for transmission by the fungus Polymyxa betae. $J$. Gen. Virol. 72:1497-1504.

Weiland, J. J., Larson, R. L., Freeman, T. P. and Edwards, M. C. 2006. First report of Beet black scorch virus in the United States. Plant Dis. 90:828.

Yassi, M. N. A., Ritzenthaler, C., Brugidou, C., Fauquet, C. and Beachy, R. N. 1994. Nucleotide sequence and genome characterization of Rice yellow mottle virus RNA. J. Gen. Virol. 75:249-257. 